\title{
Analisis Varians Sebagai Alat Pengendali Manajemen pada Departemen Produksi PT Surya Sakti Utama Surabaya
}

\author{
Budi Utami $^{1}$, Eny Setyariningsih ${ }^{2}$ \\ utamiwahjoe@gmail.com ${ }^{1}$, eny.se888@gmail.com ${ }^{2}$ \\ Fakultas Ekonomi Universitas Islam Majapahit \\ Jl. Raya Jabon KM 0,7, Gayaman, Mojoanyar, Mojokerto, Jawa Timur 61364 \\ Telp/fax (0321) 399474 - Website : www.unim.ac.id
}

\begin{abstract}
ABSTRAK
Budgeting atau penganggaran merupakan suatu proses perencanaan dan pengendalian kegiatan operasi perusahaan yang dinyatakan dalam satuan kegiatan dan satuan uang yang bertujuan untuk memproyeksikan operasi perusahaan tersebut dalam proyeksi laporan keuangan. Kegiatan produksi adalah salah satu fungsi dalam kegiatan perusahaan yang membutuhkan perencanaan dan pengendalian manajemen, karena proses tersebut melibatkan berbagai sumber daya yang harus dimanfaatkan secara efisien, sehingga pengendalian terhadap kegiatan tersebut ikut menentukan berhasil tidaknya suatu perusahaan dalam mencapai tujuannya.

Pengendalian manajemen dalam bidang produksi dilakukan melalui aktifitas penganggaran. Penganggaran atau budgeting merupakan suatu hal yang dipandang perlu mengingat peranannya dalam menunjang efektifitas dan efisiensi kegiatan produksi. Keberhasilan fungsi produksi sangat tergantung pada perencanaan dan pengendalian kegiatan produksi itu sendiri. Dengan adanya sistem pengendalian maka produksi dapat menunjang efisiensi.

PT Surya Sakti Utama adalah perusahaan yang berkembang pesat dan bergerak dalam bidang alas kaki. Pengendalian manajemen pada departemen produksi PT Surya Sakti Utama dilakukan dengan menggunakan analisis varians dan metode tiga selisih. Metode ini menghitung selisih antara pemakaian aktual dan pemakaian standar / yang dianggarkan. Pengendalian manajemen dilakukan pada bahan baku, tenagakerja langsung dan BOP.
\end{abstract}

Kata kunci: analisis varians, metode tiga selisih, bahan baku, tenaga kerja langsung, BOP.

\section{PENDAHULUAN}

Salah satu indikator keberhasilan menjalankan suatu usaha terletak pada kemampuan manajemen dalam mengawasi dan mengendalikan semua kegiatan yang ada didalam perusahaan. Masalah akan timbul ketika perusahaan semakin berkembang dan bertambah besar, karena hal ini menuntut kemampuan yang lebih besar dari manajemen untuk mengawasi dan mengendalikan semua kegiatan yang terjadi di dalam perusahaan. Ketidakmampuan ataupun kelemahan dalam hal ini akan mengakibatkan ketidakefektifan dan ketidakefesiensian dalam operasi perusahaan. 
Kegiatan produksi adalah salah satu fungsi dalam kegiatan perusahaan yang membutuhkan perencanaan dan pengendalian manajemen, karena proses tersebut melibatkan berbagai sumber daya yang harus dimanfaatkan secara efisien, sehingga pengendalian terhadap kegiatan tersebut ikut menentukan berhasil tidaknya suatu perusahaan dalam mencapai tujuannya.

Pengendalian (control) merupakan usaha sistematis perusahaan untuk mencapai tujuan dengan cara membandingkan prestasi kerja dengan rencana dan membuat tindakan yang tepat untuk mengoreksi perbedaan yang penting. ${ }^{1}$ Pengendalian manajemen merupakan semua metode, prosedur dan siasat, termasuk sistem yang digunakan oleh manajemen untuk menjamin bahwa pelaksanaan sesuai dengan strategi dan kebijakan organisasi ${ }^{2}$. Sistem pengendalian manajemen adalah sebuah sistem yang terdiri dari beberapa sub sistem yang saling berkaitan yaitu pemprograman, akuntansi, pelaporan dan tanggung jawab.

Pengendalian manajemen dalam bidang produksi merupakan suatu hal yang dipandang perlu mengingat peranannya dalam menunjang efektifitas dan efisiensi kegiatan produksi. Keberhasilan fungsi produksi sangat tergantung pada perencanaan dan pengendalian kegiatan produksi itu sendiri.Dalam suatu persaingan, adanya sistem pengendalian produksi dapat menunjang efisiensi. Pengendalian manajemen terhadap kegiatan produksi perusahaan tidak bias dipandang sebagai suatu hal yang remeh karena perencanaan dan pengendaliaan yang baik ikut menentukan berhasil tidaknya suatu perusahaan dalam mencapai tujuannya.

Didalam pengendalian manajemen terdiri dari beberapa fungsi yang antara lain fungsi produksi, fungsi pemasaran, fungsi keuangan serta fungsi personalia. Dari berbagai fungsi tersebut saling berhubungan dan merupakan satu kesatuan yang tidak dapat dipisah-pisahkan dalam operasi perusahaan, juga merupakan suatu system yang mempunyai tugas yang berbeda-beda dan harus berjalan seimbang, sehingga tercipta kerjasama yang membuahkan hasil sesuai dengan tujuan perusahaan.Suatuf ungsi dapat dikatakan berjalan baik apabila fungsi tersebut dapat menjalankan aktifitasnya secara efektif dan efisien.

PT Surya Sakti Utama perusahaan yang bergerak di bidang industri alas kaki. Pertumbuhan perusahaan yang semakin pesat menjadikan aktivitas perusahaan semakin kompleks, sehingga perusahaan dalam hal ini dituntut untuk lebih banyak melakukan pengawasan dan pengendalian, salah satunya adalah pengawasan dan pengendalian di departemen produksi.

\section{RUMUSAN MASALAH}

1. Bagaimanakah pengendalian bahan baku dengan menggunakan analisis varians pada departemen produksi PT Surya Sakti Utama?

2. Bagaimanakah pengendalian tenaga kerja dengan menggunakan analisis varians pada departemen produksi PT Surya Sakti Utama?

3. Bagaimanakah pengendalian biaya overhead pabrik dengan menggunakan analisis varians pada departemen produksi PT Surya Sakti Utama? 


\section{METODE PENELITIAN}

Jenis penelitian yang digunakan dalam penelitian adalah studi kasus. Pelaksanaan penelitian ini dilakukan ditempat atau dalam kehidupan yang sebenarnya dari objek yang akan diteliti. Metode kasus dalam penelitian ini bertujuan memaparkan data tentang objek, menginteprestasikan dan membandingkan dengan teori yang ada hubungannya dengan topik pembahasan. Data yang digunakan dalam penelitian ini adalah data sekunder yang meliputi data-data pada departemen produksi PT. Surya Sakti Utama pada tahun 2017 dan 2018. Metode analisa yang digunakan adalah : metode analisa selisih / analisa varians.

\section{Selisih $($ Variance $)=$ Budget - Realisasi}

- Analisis selisih biaya bahan baku

- Analisis selisih biaya tenaga kerja

- Analisis selisih biaya overhead pabrik menggunakan Metode tiga selisih.

\section{ANALISA DAN PEMBAHASAN}

PT. Surya Sakti Utama dalam melaksanakan kegiatan produksinya menyusun satu anggaran tahunan dengan tujuan agar lebih terarah dalam kegiatan produksi. Anggaran disusun untuk merealisasikan dengan rencana yang telah disusun berdasarkan tahun-tahun sebelumnya. Dalam melakukan penetapan besarnya budget produksi untuk masing-masing biaya hanya didasarkan pada biaya yang dikeluarkan pada tahun lalu ditambah prosentase tertentu (besarnya $10 \%$ ) untuk menjaga kenaikkan biaya, tanpa memperhitungkan kemungkinan biaya tahun lalu terselip adanya pemborosan inefisiensi. Persetujuan terhadap anggaran yang dibuat sepenuhnya tergantung pimpinan perusahaan dengan berbagai pertimbangan-pertimbangan. 
Tabel 1

PT. Surya Sakti Utama

Angggaran Biaya Produksi

Tahun 2017

\begin{tabular}{|c|c|}
\hline Jenis Biaya & Anggaran (Rp) \\
\hline \multicolumn{2}{|l|}{ Biaya produksi langsung } \\
\hline - Biaya bahan baku & 1.041 .707 .000 \\
\hline - $\quad$ Biaya TKL & 942.101 .000 \\
\hline \multicolumn{2}{|l|}{ Biaya produksi tak langsung } \\
\hline - Biaya penolong & 300.000 .000 \\
\hline - Biaya tenaga kerja tak langsung & 75.750 .000 \\
\hline - Biaya pemeliharaan mesin/alat & 117.763 .000 \\
\hline - Biaya pemeliharaan kendaraan & 2.000 .000 \\
\hline - Biaya pemeliharaan gedung & 1.500 .000 \\
\hline - Biaya penyusutan mesin/alat & 159.977 .000 \\
\hline - Biaya penyusutan kendaraan & 8.629 .940 \\
\hline - Biaya penyusutan gedung & 9.239 .300 \\
\hline - Biaya listrik & 232.581 .000 \\
\hline - Biaya bungkus & 176.644 .000 \\
\hline Total & 3.067 .892 .240 \\
\hline
\end{tabular}

Tabel 2

PT. Surya Sakti Utama

Angggaran Biaya Produksi

Tahun 2018

\begin{tabular}{|c|c|}
\hline Jenis Biaya & Anggaran (Rp) \\
\hline \multicolumn{2}{|l|}{ Biaya produksi langsung } \\
\hline - Biaya bahan baku & 1.116.177.700 \\
\hline - Biaya TKL & 1.067.137.500 \\
\hline \multicolumn{2}{|l|}{ Biaya produksi tak langsung } \\
\hline - Biaya penolong & 187.934 .400 \\
\hline - Biaya tenaga kerja tak langsung & 83.325 .000 \\
\hline - Biaya pemeliharaan mesin/alat & \\
\hline - Biaya pemeliharaan kendaraan & 131.024 .300 \\
\hline - Biaya pemeliharaan gedung & 1.870 .000 \\
\hline - Biaya penyusutan mesin/alat & 1.320 .000 \\
\hline - Biaya penyusutan kendaraan & 175.974 .700 \\
\hline - Biaya penyusutan gedung & 3.479 .234 \\
\hline - Biaya listrik & 10.163 .230 \\
\hline \multirow[t]{2}{*}{ - Biaya bungkus } & 255.839 .100 \\
\hline & 194.308 .400 \\
\hline Total & 3.228 .558 .564 \\
\hline
\end{tabular}

Bisman (Bisnis dan Manajemen): The Journal Of Business and Management 
Tabel 3

PT. Surya Sakti Utama

Realisasi Biaya Produksi

Tahun 2017

\begin{tabular}{|lr|}
\hline \multicolumn{1}{|c|}{ Jenis Biaya } & \multicolumn{1}{c|}{ Realisasi } \\
\hline Biaya Produksi Langsung & \\
- Biaya Bahan Baku & 1.041 .707 .000 \\
- Biaya TKL & 970.125 .000 \\
Biaya Produksi Tak Langsung & \\
- Bahan Penolong & 170.854 .000 \\
- Biaya tenaga kerja tak langsung & 75.750 .000 \\
- Biaya pemeliharaan mesin/alat & 119.113 .000 \\
- Biaya pemeliharaan kendaraan & 1.700 .000 \\
- Biaya pemeliharaan gedung & 1.200 .000 \\
- Biaya penyusutan mesin/alat & 159.977 .000 \\
- Biaya penyusutan kendaraan & 3.162 .940 \\
- Biaya penyusutan gedung & 9.329 .300 \\
- Biaya listrik & 232.581 .000 \\
- Biaya bungkus & 176.644 .000 \\
\hline Total & $\mathbf{2 . 9 6 2 . 0 5 3 . 2 4 0}$ \\
\hline
\end{tabular}

\section{Tabel 4}

PT. Surya Sakti Utama

Realisasi Biaya Produksi

Tahun 2018

\begin{tabular}{|lr|}
\hline \multicolumn{1}{|c|}{ Jenis Biaya } & \multicolumn{1}{c|}{ Realisasi } \\
\hline Biaya Produksi Langsung & \\
- Biaya Bahan Baku & 1.112 .927 .000 \\
- Biaya TKL & 1.070 .687 .000 \\
Biaya Produksi Tak Langsung & \\
- Bahan Penolong & 90.026 .000 \\
- Biaya tenaga kerja tak langsung & 86.453 .000 \\
- Biaya pemeliharaan mesin/alat & 132.269 .350 \\
- Biaya pemeliharaan kendaraan & 2.730 .000 \\
- Biaya pemeliharaan gedung & 1.120 .000 \\
- Biaya penyusutan mesin/alat & 175.974 .700 \\
- Biaya penyusutan kendaraan & 3.479 .234 \\
- Biaya penyusutan gedung & 10.163 .230 \\
- Biaya listrik & 270.186 .500 \\
- Biaya bungkus & 176.644 .000 \\
\hline Total & $\mathbf{3 . 0 6 0 . 8 7 7 . 3 5 3}$ \\
\hline
\end{tabular}

Adapun target dan realisasi produksi untuk tahun 2017 dan tahun 2018 adalah sebagai berikut:

Bisman (Bisnis dan Manajemen): The Journal Of Business and Management 
Tabel 5

PT. SURYA SAKTI UTAMA

TARGET DAN REALISASI PRODUKSI

TAHUN 2017 DAN 2018

\begin{tabular}{|ccrrrr|}
\hline Tahun & $\begin{array}{c}\text { Unit } \\
\text { Target }\end{array}$ & $\begin{array}{c}\text { Unit } \\
\text { Realisasi }\end{array}$ & Unit selisih & \% Target & Keterangan \\
\hline 2017 & 300.000 & 280.900 & 19.100 & 93,64 & Tidak terealissi \\
2018 & 300.000 & 290.700 & 9.300 & 96,90 & Tidak terealissi \\
\hline
\end{tabular}

Dari data diatas, untuk tahun 2017 dan tahun 2018 target produksi belum terealisasikan, meskipun untuk tahun 2018 ada kenaikkan sebesar 9.800 unit. Ini disebabkan kurangnya persediaan bahan baku di gudang akibat terlambatnya pengiriman bahan baku dari produsen.

\section{Tabel 6}

PT. SURYA SAKTI UTAMA

TARGET DAN REALISASI BIAYA PRODUKSI

TAHUN 2017 DAN 2018

\begin{tabular}{|ccccc|}
\hline $\begin{array}{c}\text { Keterangan } \\
\text { Tahun }\end{array}$ & $\begin{array}{c}\text { Anggaran } \\
(\mathbf{R p})\end{array}$ & Realisasi (Rp) & Selisih (Rp) & Keterangan \\
\hline 2017 & 3.067 .892 .240 & 2.962 .053 .240 & 105.839 .000 & $\mathrm{~F}$ \\
\hline 2018 & 3.228 .558 .564 & 3.060 .877 .353 & 167.711 .211 & $\mathrm{~F}$ \\
\hline
\end{tabular}

Dari data diatas untuk tahun 2017 dan tahun 2018 anggaran biaya produksi lebih besar dari yang terealisasi. Hal ini menimbulkan selisih yang menguntungkan ( $\mathrm{F}=$ favorable).

Laporan realisasi anggaran produksi yang dibuat PT. Surya Sakti Utama menyajikan hasil produksi serta biaya-biaya yang terjadi sehubungan dengan proses produksi. Analisa lebih lanjut perlu dilakukan terhadap selisih yang terjadi antara anggaran dan realisasinya.

Selisih harga $\mathrm{BB}=\mathrm{Sh}=(\mathrm{Hs}-\mathrm{Ha}) \times \mathrm{Ka}$

Selisih pemakaian $\mathrm{BB}=(\mathrm{Ka}-\mathrm{Ks}) \times \mathrm{Ha}$

Dimana :

$\mathrm{Ha} \quad=$ harga actual bahan baku

Hs = harga standart bahan baku

$\mathrm{Ka}=$ kuantitas actual bahan baku

Ks = kuantitas standart bahan baku

\section{Tabel 7}

Standart Pembelian Dan Pemakaian Bahan Baku PT. Surya Sakti Utama Surabaya

\begin{tabular}{lrrr}
\hline Bahan langsung & Kuantitas & Harga/Kg & Total \\
Kalsium & $198.450 \mathrm{~kg}$ & Rp 2150 & Rp 426.667.500 \\
Karet seer & $99.380 \mathrm{~kg}$ & Rp 1900 & Rp 188.822.000 \\
Eva & $59.845 \mathrm{~kg}$ & Rp 1800 & Rp 107.721.000 \\
PE & $261.980 \mathrm{~kg}$ & Rp 1500 & Rp 392.967.200 \\
Total standart biaya bahan baku & & Rp 1.166.177.000 \\
\hline
\end{tabular}

Bisman (Bisnis dan Manajemen): The Journal Of Business and Management 
Tabel 8

Realisasi Pembelian Dan Pemakaian Bahan Baku PT. Surya Sakti Utama

\begin{tabular}{ccccc}
\hline Bahan langsung & kuantitas & harga/kg & & total \\
Kalsium & $197.000 \mathrm{~kg}$ & $\mathrm{Rp} 2.145$ & $\mathrm{Rp}$ & 422.565 .000 \\
Karet seer & $95.600 \mathrm{~kg}$ & $\mathrm{Rp} 1.875$ & $\mathrm{Rp}$ & 179.250 .000 \\
Eva & $58.900 \mathrm{~kg}$ & $\mathrm{Rp} 1.775$ & $\mathrm{Rp}$ & 104.947 .500 \\
PE & $203.598 \mathrm{~kg}$ & $\mathrm{Rp} 1.480$ & $\mathrm{Rp} 301.325 .500$ \\
Total standart biaya bahan baku & & & $\mathrm{Rp} 1.008 .088 .000$ \\
\hline
\end{tabular}

Analisis selisih biaya bahan baku:

Selisih Harga Bahan Baku $=\mathrm{Sh}=(\mathrm{Hs}-\mathrm{Ha}) \times$ Ps

Untuk kalsium : $\mathrm{Sh}=(2145-2150) \times 197.000=\mathrm{Rp} 985.000$

Untuk Karet Seer : $\mathrm{Sh}=(1875-1900) \times 95.600=2.390 .000$

Untuk Eva : $\mathrm{Sh}=(1775-1800) \times 58.900=1.472 .500$

Untuk PE : Sh $=(1480-1500) \times 203.598=4.071 .960$

Total selisih harga bahan baku adalah :Rp 8.919.460

Selisih yang menguntungkan sebesar Rp 8.919.460 ini disebabkan pembelian harga bahan baku sesungguhnya lebih kecil dari harga bahan standart, dalam hal ini harga masih dapat dikendalikan oleh perusahaan.

\section{Selisih Kuantitas Bahan Baku}

Untuk kalsium : $\mathrm{Sk}=(197.000-198.450)$ x $2150=\mathrm{Rp} 3.117 .500$

Untuk karet : $\mathrm{Sk}=(95.600-99.380) \times 1900=\mathrm{Rp} 7.182 .000$

Untuk Eva $=\mathrm{Sk} \quad=(58.900-59.845) \times 1800=\mathrm{Rp} 701.000$

Untuk PE : Sk $\quad=(203.598-261.980) \times 1500=R p 87.573 .000$

Total selisih kuantita bahan baku adalah :nRp 99.573.500

\section{Analisis biaya tenaga kerja langsung}

$\mathrm{Se}=(\mathrm{Ws}-\mathrm{Wa}) \times \mathrm{Ta}$

Dimana :

$\mathrm{Se}=$ selisih efisiensi

Ws = waktu Sesungguhnya

$\mathrm{Wa}=$ Waktu yang di anggarkan

$\mathrm{Ta}=$ Tarif upah standar

Diketahui : Jumlah jam kerja seluruhnya $=183.610$ jam $(\mathrm{Ws})$

Jumlah jam kerja standart $\quad=180.600$ jam $(\mathrm{Wa})$

Tarif upah perjam standart $\quad=$ Rp.592,262 $(\mathrm{Ta})$

Total selisih efisiensi :

$\mathrm{Se}=(\mathrm{Ws}-\mathrm{Wa}) \times \mathrm{Ta}=(183.610-180.600) \times 592,262=1.782 .708 .62$

Total selisih efisien tenaga kerja langsung tidak menguntungkan sebesar Rp. 1.782.708,62 karena jam kerja sesungguhnya lebih besar dari jam kerja yang dianggarkan.

Selisih tetap 
Selisih dapat dirumuskan dengan rumus :

$\mathbf{S t}=(\mathbf{T s}-\mathbf{T a}) \mathbf{x W s}$

Dimanai :

$\mathrm{St}=$ selisih tarif upah

Ts $=$ tarif sesungguhnya

$\mathrm{Ta}=$ tarifyang dianggarkan

$\mathrm{Wa}=$ waktu sesungguhnya

Diketahui : tarif upah perjam sesungguhnya Rp. 592,26 (Ts)

Tariff upah perjam standart Rp534,52 (Ta)

Jumlah jam kerja sesungguhnya Rp. 30.601,5 jam (Wa)

\section{Analisis Selisih Biaya Overhead Pabrik}

Tabel 8

Standar BOP PT. "SS" Utama Surabaya tahun 2009

\begin{tabular}{|lcc|}
\hline \multicolumn{1}{|c|}{ Keterangan } & Biaya Variabel & Biaya Tetap \\
\hline Bahan Penolong & Rp. 187.939.400 & \\
Biaya TKTL & Rp. 83.325.000 & \\
Biaya pemeliharaan Kendaraan, & Rp. 134.214.300 & \\
Gedung, dan mesin / alat dan & & Rp.189.617.164 \\
kendaraan. & & \\
Biaya Listrik & Rp. 255.839.100 & \\
Biaya bungkus & Rp. 194.308.400 & Rp. 189.617.164 \\
\hline
\end{tabular}

Total : 1.045.243.364

Tabel 9

Realisasi BOP PT "SS" Utama Surabaya Tahun 2009

\begin{tabular}{|lrc|}
\hline \multicolumn{1}{|c|}{ Keterangan } & Biaya Variabel & Biaya Tetap \\
\hline $\begin{array}{l}\text { Bahan Penolong } \\
\text { Biaya TKTL }\end{array}$ & Rp. 90.026.400 & \\
$\begin{array}{l}\text { Biaya pemeliharaan Kendaraan, } \\
\text { Gedung, dan mesin / alat dan } \\
\text { kendaraan. }\end{array}$ & Rp. 136.119.350 & \\
$\begin{array}{l}\text { Biaya Listrik } \\
\text { Biaya bungkus }\end{array}$ & Rp. 270.186.500 & Rp.189.617.164 \\
\hline & Rp. 209.308.400 & \\
\hline
\end{tabular}

\section{Total : 1.045.243.364}

Karena perusahaan hanya mempunyai tarif upah harian, maka untuk analisis BOP, perusahaan harus mempunyai tarif uupah perjam yang ditentukan dari jumlah biaya yang diperkirakan selama satu tahun dibagi dengan kapasitas normal jam kerja langsung. Untuk perhitungan tarif biaya overhead pabrik dan kapasitas normal kerja karyawan dalam hari dijadikan kapasitas normal kerja dalam jam. 
Diketahui total jam kerja untuk tahun 2018 :179.396 jam

a. BOP actual Rp 980.102.241

BOP tetap pada kapasitas normal (179.396 x 1056)

BOP variabel sesungguhnya $\frac{\operatorname{Rp} 189.442 .176}{\operatorname{Rp} 790.660 .038}$

BOP variabel yang dianggarkan

Pada jam sesungguhnya dicapai

(183.610 x 4.417)

Rp 811.055.370

selisih pengeluaran Rp 20.395.332( TE)

b. Kapasitas normal

Kapasitas sesungguhnya

Kapasitas tidak terpakai

Tarif BOP tetap

Selisih kapasitas

179.396 jam

$183.610 \mathrm{jam}$

$\begin{array}{cc} & 1.214 \\ \text { Rp } \quad 1.056 x\end{array}$

c. Jam standart

180.600

Jam sesungguhnya

183.610

Selisih efisiensi

3.010

Tarif BOP

Selisih efisiensi

$\mathrm{Rp} \mathrm{4.449.984}$

\begin{tabular}{l}
180.600 \\
183.610 \\
3.010 \\
$\operatorname{Rp} \quad 4.417 \quad x$ \\
\hline $\operatorname{Rp} 13.295 .170(\mathrm{TE})$ \\
\hline \hline
\end{tabular}

\section{Metode tiga selisih}

Selisih pengeluaran

Selisih ini desebabkan biaya overhead pabrik variabel sesungguhnya lebih kecil dari biaya overhead pabrik yang dianggarkan pada jam sesungguhnya. Biaya overhead pabrik yang sesungguhnya Rp. 980 .102. 214. sedang biaya overhead pabrik yang dianggarkan pada jam sesungguhnya Rp. 811.055.370,. selisih ini tidak menguntungkan bagi bagian produksi.

\section{Selisih kapasitas}

Selisih ini disebabkan karena perusahaan bekerja diatas kapasitas normal . Kapasitas normal 179.396 jam sedang kapasitas sesunggunya 183.600 jam .

\section{Selisih efisiensi}

Selisih ini disebabkan perbadaan antara jam kerja standar denan jam kerja sesungguhnya. Jam kerja standar 180.600 jam, sedang jam sesungguhnya 183.610. 
Tabel 10

PT. Surya Sakti Utama

Analisis Variance Biaya Produksi tahun 2017

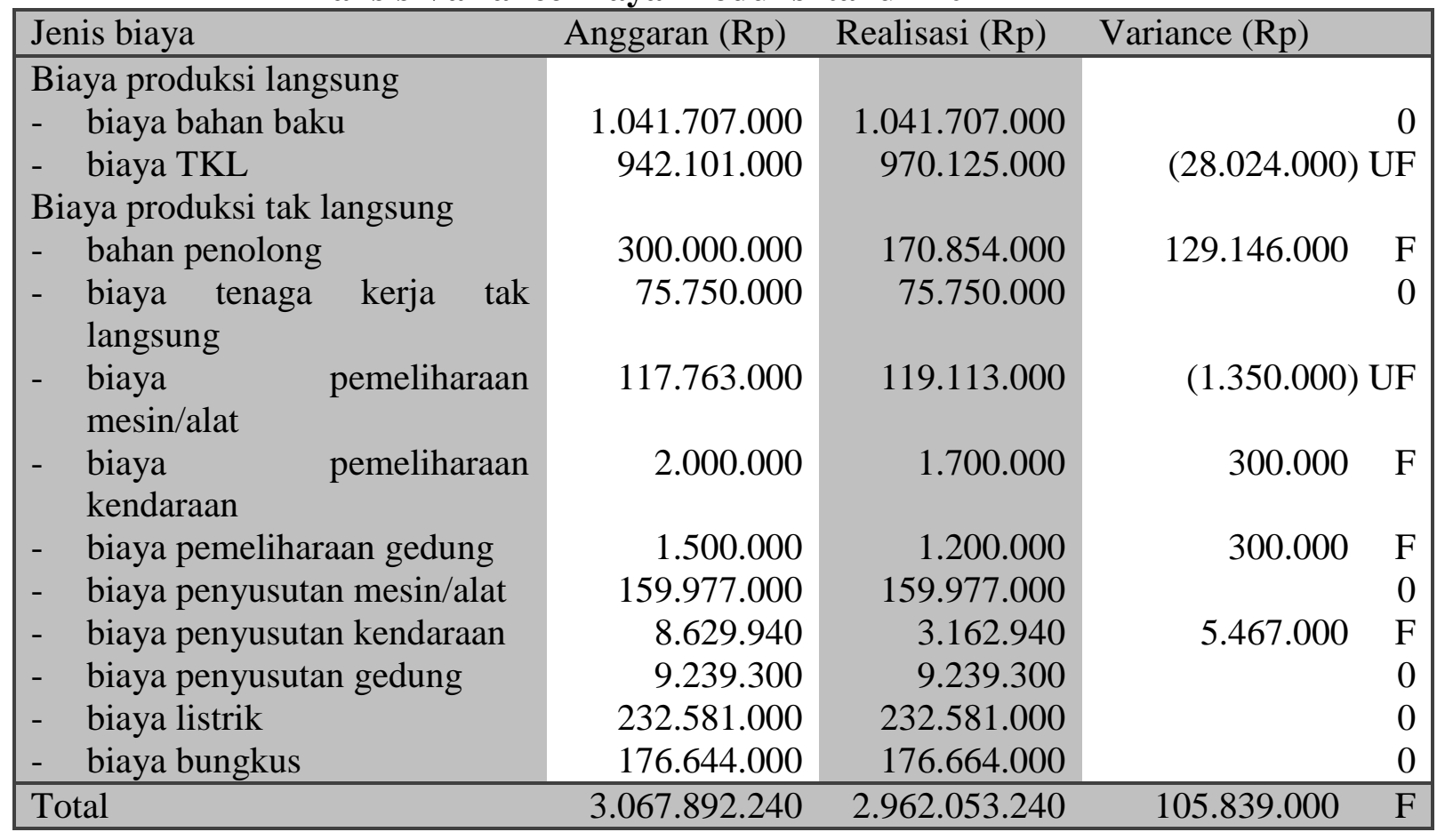

Bisman (Bisnis dan Manajemen): The Journal Of Business and Management 
Tabel 11

PT. Surya Sakti Utama

Ananlisis Variance Biaya Produksi tahun 2018

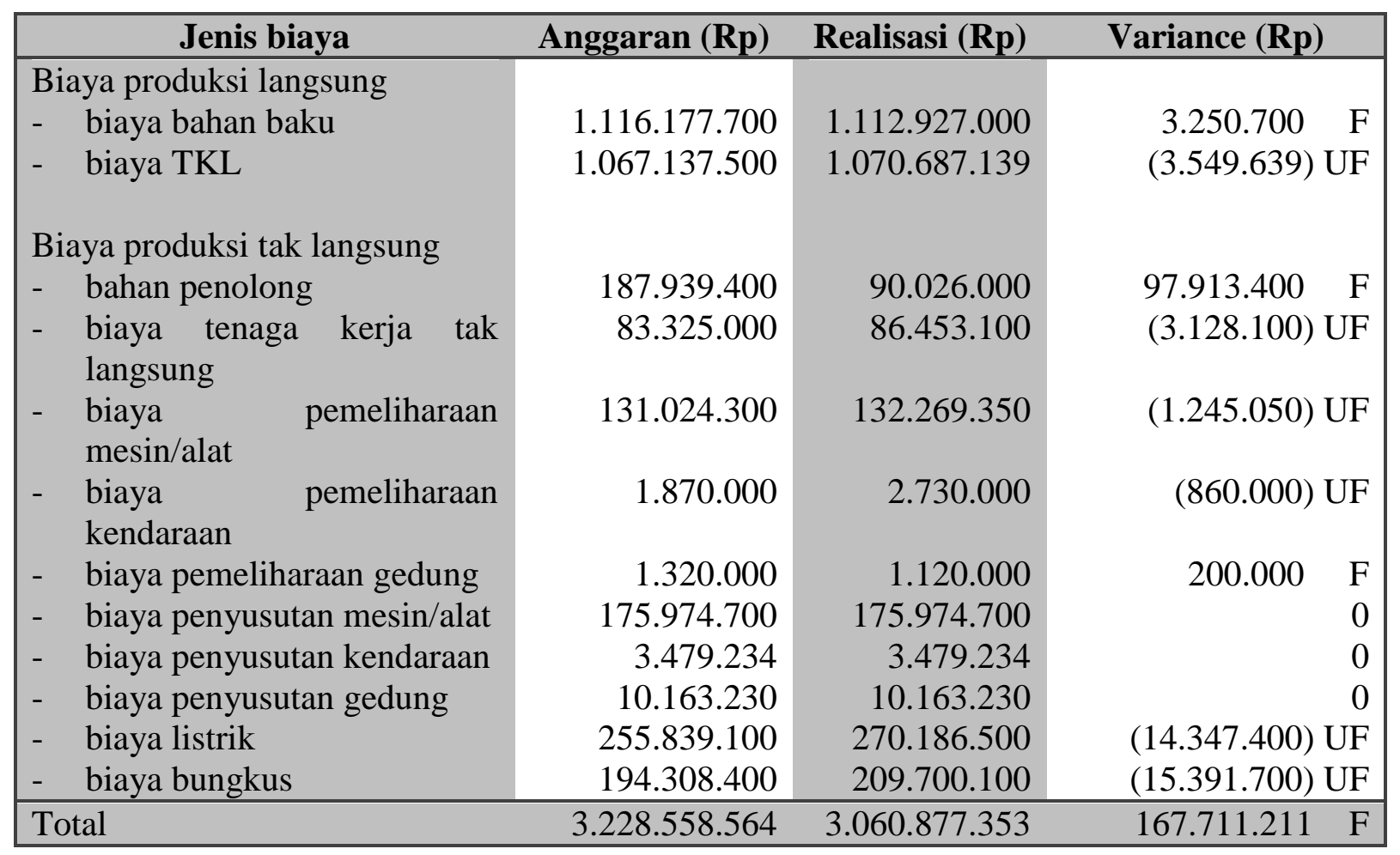

1. Analisis untuk tahun 2017

Budget dan realisai keuangan PT. Surya Sakti Utama,terdapat variance favorable pada tahun 2017 yaitu sebesar 105.839.000 dari RP.3.067.892.240 yang direncanakan . Adapun informasi mengenai adanya variance biaya yang favorable dapat dijelaskan sebagai berikut:

a. adanya realisasi biaya bahan penolong yang lebih sedikit dari yang dianggarkan.

b. adanya realisasi biaya pemeliharan kendaran yang lebih sedikit dari yang dianggarkan

c. adanya realiasi biaya pemeliharan gedung yang lebih sedikit yang dianggarkan

d. adanya realisasi biaya penyusutan kendaraan yang lebih sedikit dari yang dianggarkan sebelumnya.

Sedangkan informasi mengenai adanya beberapa variance biaya yang unfavorable dapat dijelaskan sebagai berikut :

a. adanya penambahan biaya tenaga kerja langsung yang tidak terdefinisikan sebelumnya sehingga anggaran yang dibuat tidak mendekati realisasinya.

b. adanya kerusakan mesin / alat yang sering kali tak terduga, sehingga sering kali terjadi variance yang cukup immaterial. 
2. Analisis untuk tahun 2018 pada tahun itu terdapat variance favorable sebesar $\mathrm{Rp}$ 167.711.211. dari $\mathrm{Rp}$ 3.228.558.564. yang direncanaka. adapun informasi mengenai adanya beberapa variance biaya yang favorable dapat dijelaskan sebagai berikut :

a. Adanya realisasi biaya bahan baku yang lebih sedikit dari yang dianggarkan.

b. Adanya realisasi biaya pemeliharaan gedung yang lebih sedikit dari yang dianggarkan.

c. Adanya realisasi biaya bahan penolong yang lebih sedikit dari yang dianggarkan sebelumnya sehingga dapat mengurani anggaran dan menambah keuntungan secara keseluruhan.

Sedangkan informasi mengenai adanya beberapa variance biaya yang unfavorable dapat dijelaskan sebagai berikut :

a. adanya kenaikkan upah tenaga kerja tak langsung yang belum terdefenisikan dalam anggaran.

b. Adanya biaya tak terduga untuk pemeliharaan mesin/alat dan kendaraan perusahaan.

c. Adanya pemborosan penggunaan listrik, sehingga anggaran yang dibuat tidak mendekati realisasi.

d. Adanya penambahan biaya pembungkusan yang tak terduga sebelumnya dan tidak sesuai dengan yang direncanakan.

e. Adanya realisasi biaya tenaga kerja langsung yang lebih besar dari yang dianggarkan sebelumnya.

\section{PENUTUP}

Setelah dilakukan perhitungan biaya antara budget dan realisasinya menghasilkan selisih (variance) yang menguntungkan, akan tetapi kalau dilihat dari hasil keseluruhan produksi yang telah dicapai oleh PT. Surya Sakti Utama belum bisa dikatakan efektif, karena target produksi yang diharapkan belum terpenuhi, dalam artian hasil produksi masih dibawah target produksi yang diharapkan .walaupun dari segi biaya bisa dikatakan efisien, dalam artian secara keseluruhan baik pada tahun 2017 dan tahun 2018 terdapat selisih yang menguntungkan antara anggaran di realisasi hal ini terjadi karena total anggaran pada tahun 2017 dan tahun 2018 lebih besar dari biaya yang terealisasi. Tetapi apabila diamati secara lebih rinci maka akan diketahui biaya-biaya yang juga mengalami kenaikan dari yang dianggarkan maka untuk langkah selanjutnya adalah menganalisis biaya yang terjadi untuk tahun 2017 dan tahun 2018 


\section{DAFTAR PUSTAKA}

Any Agus Kana. Anggaran Perusahaa.aK Group. Yogyakarta.

Edi Harman. 2006. Penganggaran Korporasi Suatu Pendekatan Integratif. PT Raja Grafindo Perkasa.

Ellen cristina. 2002. Anggaran Perusahaan Suatu Pendekatan Praktis. Edisi 2. PT SUN. Jakarta.

Gunawan Adi Saputro, Marwan Asri. 1998. Anggaran Perusahaan Buku 1 dan 2. Edisi Ketiga. BPFE. Yogyakarta.

Haruman, Tendi \& Rahayu, Sri. 2007. Penyusunan Anggaran Perusahaan. Edisi Kedua. Graha Ilmu. Yogyakarta.

M. Munandar. 1997. Budgeting Perencanaan Kerja Pengkoordinasian Kerja Pengawasan Kerja. Edeisi Pertama. BPFE. Yogyakarta.

Y. Supriyanto. 1995. Anggaran Perusahaan Perencanaan dan Pengendalian Laba. Edisi Pertama. YKPN. Yogyakarta. 